\title{
Dietary Exposure of the Red-Crowned Crane (Grus japonensis) to Total and Methyl Mercury in Zhalong Wetland, Northeastern China
}

\author{
Jinming Luo • Yajie Ye • Yongjie Wang
}

Received: 10 March 2014 / Accepted: 23 April 2014 / Published online: 3 May 2014

(C) The Author(s) 2014. This article is published with open access at Springerlink.com

\begin{abstract}
To determine the dietary exposure of the migratory red-crowned crane to mercury $(\mathrm{Hg})$, this study analyzed the concentrations of total mercury ( $\mathrm{T}-\mathrm{Hg}$ ) and methyl mercury $(\mathrm{MeHg})$ in its prey, i.e., reeds and three aquatic animal families (Perccottus glenni Dybowski, Cybister japonicus Sharp, and Viviparidae) in northeastern China. Results indicated that the $\mathrm{Hg}$ concentration in Zhalong Wetland was elevated through the food chain, and the prey of the red-crowned crane contained measurable levels of T-Hg and MeHg. In prey tissues, $\mathrm{MeHg}$ was the main form of the $\mathrm{Hg}$ element and accounted for $61 \%$ of total $\mathrm{Hg}$ concentration in Viviparidae, $58 \%$ in C. japonicus Sharp, and $85 \%$ in P. glenni Dybowski. The highest T-Hg and MeHg concentrations ranged from 1.66 to $3.89 \mathrm{ppm}$ and from 1.12 to $2.67 \mathrm{ppm}$, respectively, and they were detected in the feathers of the red-crowned cranes. The lowest $\mathrm{T}-\mathrm{Hg}$ concentration was determined in the excretions of wild red-crowned cranes at $0.21 \mathrm{ppm}$; furthermore, the content of MeHg was below the detection limit. In Zhalong Wetland, the level of dietary exposure of the population of red-crowned cranes to $\mathrm{Hg}$ is below the threshold of $\mathrm{Hg}$ toxicity. Moreover, eggshells are suitable indicators of $\mathrm{Hg}$ risk levels to the red-crowned crane.
\end{abstract}

Keywords Habitat of red-crowned crane $\cdot$ Reed $\cdot$ Aquatic animal $\cdot$ Mercury contamination

\section{Introduction}

Mercury $(\mathrm{Hg})$ is a relatively common element in the environment and comes in various organic and inorganic forms.

J. Luo $(\bowtie) \cdot Y$. Ye $\cdot$ Y. Wang

Department of Science, Qiqihar University, 161006 Qiqihar, People's

Republic of China

e-mail: Luojm1000@sina.com
However, it is a primary concern for water fowls because it affects their health [1]. Hence, $\mathrm{Hg}$ is undesirable and potentially hazardous to the environment and its biota [2]. The effect of $\mathrm{Hg}$ on aquatic environments has been investigated extensively [3-5]. According to these studies, large quantities of the $\mathrm{Hg}$ that enter in these environments are often attached to particulate matter [6] and are readily taken up by plants [7]. As a result, elevated $\mathrm{Hg}$ is returned to consumers at the upper trophic level [8]. The high concentration of $\mathrm{Hg}$ in soil generally enhances the $\mathrm{Hg}$ content in plants and water animals $[9,10]$. Therefore, we must determine the buildup of $\mathrm{Hg}$ concentration in aquatic birds and their prey to detect net change in ecological systems.

Recent research has shown that the body burden of metals in animals is proportional to the metal content in the environment $[8,11,12]$. Frequently, environmentally sensitive aquatic plants (i.e., reed) [13], fish [14], and water birds are often employed to indicate the pollution levels of a metalcontaminated region [15-17].

The red-crowned crane (Grus japonensis) is a rare international species that has been near extinction since 2000, as indicated in the Red List of Endangered Species generated by the International Union for Conservation of Nature and Natural Resources [18]. Worldwide, its population is very small at 2,750 mature individuals. Although the resident population in Japan remains stable [19], the migratory population in mainland Asia continually declines because of the loss and degradation of wetlands for agricultural and industrial development [20]. Red-crowned cranes are omnivores and typically feed on aquatic plants (e.g., reed roots and stems) and water animals (e.g., fish, shells, and aquatic insects). Thus, their dietary intake of $\mathrm{Hg}$ is significantly affected by their prey [3]. This Hg eventually accumulates in the bodies of the redcrowned cranes, given that they roost and nest in stable sites for years. Thus, they may be chronically exposed to contaminated habitats and prey [21]. 
Zhalong National Nature Reserve (Zhalong Wetland), in the downstream Wuyur catchments, northeastern China, is one of the largest habitant and breeding sites for migratory red-crowned crane. More than 30 petrochemical plants located in the midstream of the catchments and large area of arable land around the wetland may bring about some amount of $\mathrm{Hg}$ accumulation and high probability of contact of cranes with the toxic chemical. An adverse factor is that all rare species such as the red-crowned cranes in China are protected in legislation, and any intentional killing of those rare water fowls is prohibited. An alternative approach is to investigate $\mathrm{Hg}$ contamination level in their habitats [13] and to examine their external tissues (e.g., feather and egg) [15, 17, 22] and excretions [16]. In our previous research, feces were found to contain a measurable level of $\mathrm{Cd}$ and suitable as an indicator for body burden of $\mathrm{Cd}$ on red-crowned crane [23]. However, data are scarce on body burden and dietary exposure to $\mathrm{Hg}$ on the water bird in this region.

This research examines the levels of total mercury (T-Hg) and methyl mercury ( $\mathrm{MeHg}$ ) in the prey of the red-crowned crane to estimate the exposure levels of red-crowned cranes and to determine whether their feathers, excretions (mainly feces), and eggshells can indicate $\mathrm{Hg}$ contamination in the bodies of these birds. The present study is the first to investigate the accumulation of $\mathrm{Hg}$ in and the dietary exposure of red-crowned cranes to this element in northeastern China. The results from this research enrich our understanding of the ecological safety of the health of migratory red-crowned cranes in China.

\section{Materials and Methods}

\section{Study Area}

The Wuyur River originates from the western foot of Xiaoxin'an Mountain, northeastern China, of which the watershed is presented to be an elongated strip and flows through the main food production zone of Heilongjiang Province in China (Fig. 1a), wherein contact with heavy metals like Hg is increased. The lower reaches of the river way are replaced by a large area of reed marsh after entering into the Zhalong Wetland. Zhalong Wetland covers an area of $2,100 \mathrm{~km}^{2}$ $\left(123^{\circ} 51^{\prime}\right.$ to $124^{\circ} 37^{\prime} \mathrm{E}, 46^{\circ} 48^{\prime}$ to $47^{\circ} 32^{\prime} \mathrm{N}$ ) (core area, which is the roosting and breeding site of endangered water birds, e.g., red-crowned cranes, is approximately $700 \mathrm{~km}^{2}$; buffer zone occupies $1,400 \mathrm{~km}^{2}$ surrounding of the core area for protecting other common water birds) (Fig. 1b). A large area of pristine reed marsh attracts a population of more than approximately 500 migratory red-crowned cranes to inhabit and breed there from the late March to the early November (approximately 8 months) per year.
Tectonically, the wetland was formed by alluvial deposits with an average altitude of $140 \mathrm{~m}$ with $4,700 \mathrm{~km}^{2}$ of agricultural land around it (Fig. 1c). River feeding and precipitation are the major sources of water in this inland reed marsh. Climatically, the wetland has a typical temperate, semiarid, and semihumid continental monsoon climate with an average annual rainfall of $410 \mathrm{~mm}$ and a potential evaporation of $1,500 \mathrm{~mm}$. The volume of runoff from upper reaches was abruptly decreased from $7.5 \times 10^{8} \mathrm{~m}^{3}$ per year in the $1980 \mathrm{~s}$ to less than $1 \times 10^{8} \mathrm{~m}^{3}$ per year in the twenty-first century. Various sludges and wasted water from the surrounding residential area, agricultural land, and industrial workshop containing several types of toxic contaminants, like $\mathrm{Hg}$, were discharged directly into the wetland without complete disposal treatment. The wastewater discharge volume increased from $0.17 \times 10^{8} \mathrm{~m}^{3}$ in 1993 to $0.45 \times 10^{8} \mathrm{~m}^{3}$ in 2010 . Increasing amount of pollution discharges elevated various toxic element concentrations not only in the sediment but also in the entire biota.

\section{Sampling Scheme}

A total of 19 sampling sites were designed for aquatic plant (i.e., reed) and aquatic animal collection. The first set of two sample sites (i.e., S1 and S2) was in the middle reaches of Wuyur catchments, the second set of ten sample sites (S3-S10, S15, and S16) was in buffer zone A of the Zhalong marsh, the third set of six sample sites (i.e., S11-S14, S17, and S18) was in the core area of the wetland, and the remaining one sample (S19) was designed in buffer zone B of the wetland (Fig. 1c). Three parts of reed organ, i.e., root, rhizome, and stem, and three aquatic animal families, i.e., Percottus glenni Dybowski, Cybister japonicus Sharp, and Viviparidae, that are typical preys of the red-crown crane in the wetland were collected at designed sampling sites (see details in Table 1). Surface sediment at each site was sampled simultaneously. All of the prey samples were rinsed thoroughly in field with distilled water to remove pollutants attached on their body, then placed in car refrigerator at $-4{ }^{\circ} \mathrm{C}$, and transported back to the laboratory.

Excretions (mainly feces) of the red-crowned cranes were collected in late October of 2011, and after-hatch residual eggshells were collected from the field in late April and early May of 2012. The outer parts of feces were carefully removed, and the core parts of the feces were picked up to avoid the influence by the sediment. We collected residual eggshell samples left by the red-crowned cranes at four nesting sites (S10, S13, S15, and S17) and excretion at sites S15 and S17. Similarly, the eggshells were washed with distilled water in the field and immediately transferred to the laboratory.

Four red-crowned crane carcasses were collected at four nesting sites: one adult crane was collected in early April of 2010 at site S10 [body weight (BW) $9.4 \mathrm{~kg}$, male]; two 
Fig. 1 Location of Wuyur catchment (a) and infield sampling design $(\mathbf{b}, \mathbf{c})$

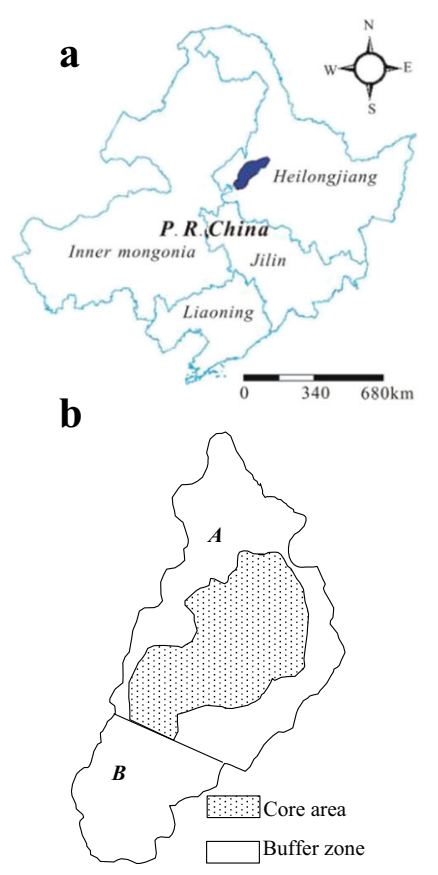

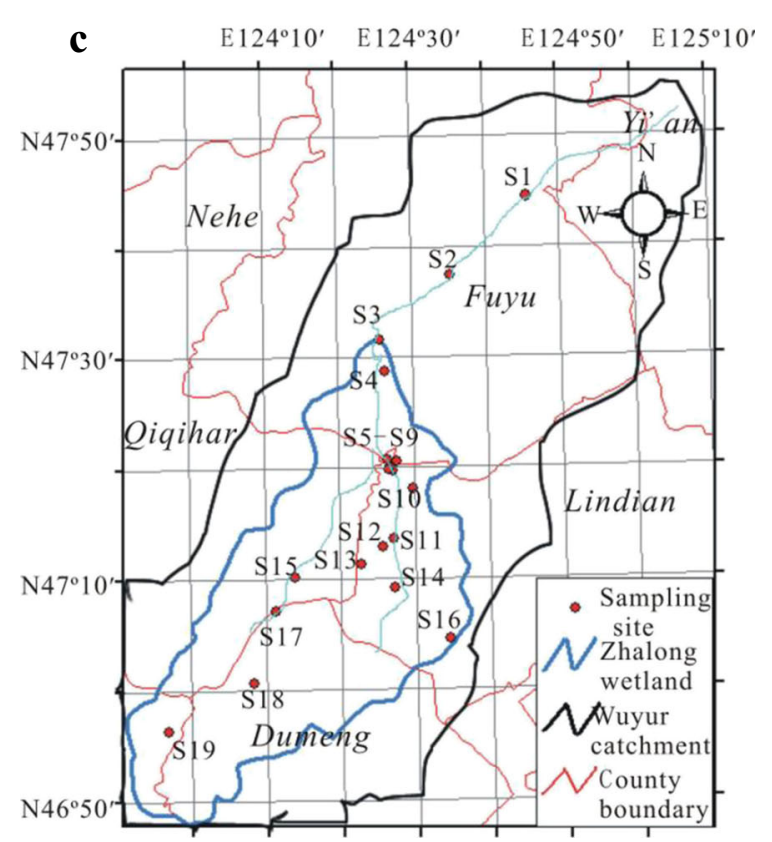

subadult cranes were found in early November at site S13 (BW $6.5 \mathrm{~kg}$, female) and site S15 (BW $6.8 \mathrm{~kg}$, male), and both dead cranes had almost no residues in their stomach, but with few grass seeds and stems; and one adult crane sample found in late October of 2012 at S17 (an obvious fracture injury was found in the right wing; BW $8.3 \mathrm{~kg}$, male). The direct death cause for these crane samples was starvation because of food shortage in freezing condition as reported by our previous research [24]. The cranes were immediately transferred to the laboratory for dissection. Approximately, 1- to 2-g samples of livers, kidney, and breast muscles were collected using a stainless steel knife. Polyethylene gloves were used throughout all dissection procedures to prevent contamination. Some flight feathers were also collected from the cranes and washed with distilled water in the laboratory.

\section{Microwave Digestion and Element Analysis}

After drying the reed organs, aquatic animal body, eggshell, and feathers of red-crowned crane samples with filter papers, these samples were oven-dried to a constant weight ( $48 \mathrm{~h}$ at $60^{\circ} \mathrm{C}$ ). The dried samples were ground to homogenous powders in a quartz bowl for acid digestion. Similar processes were performed on the feces subsamples, liver, kidney, and muscle of red-crowned crane, without washing and drying in the laboratory.

A total of $0.5 \mathrm{~g}$ of each category sample was acid digested in a microwave according to USEPA (1996) methods [25]. Five milliliters of 3:7 $\mathrm{H}_{2} \mathrm{SO}_{4}: \mathrm{HNO}_{3}$ (trace metal grade) was added to each subsample [26], which was then refluxed at about $150{ }^{\circ} \mathrm{C}$ for $3 \mathrm{~h}$. Triplicate subsamples of known dry weight were digested in acid mixture, evaporated slowly to almost dryness $\left(90^{\circ} \mathrm{C}\right)$, and the residue was dissolved in $5 \mathrm{ml}$ 1:1 diluted $\mathrm{HCl}$ and then settled to $25 \mathrm{ml}$ for analysis after the solution cooled down to room temperature.

We determined T-Hg concentration in sediments, prey tissues, and the body and excretions of a red-crowned crane using a mercury analyzer (Tekran 2600 CVAFS; Tekran Instrument Corporation, Knoxville, USA) with a detection limit of $0.005 \mathrm{\mu g} \mathrm{kg}^{-1}$. Prior to $\mathrm{Hg}$ measurement,

Table 1 Summary of numbers (Nums.) and average fresh weight (A.F.Wt.) in the three aquatic animal species sampled in the field

\begin{tabular}{lllllllllllllllllllllll}
\hline Species & & S1 & S2 & S3 & S4 & S5 & S6 & S7 & S8 & S9 & S10 & S11 & S12 & S13 & S14 & S15 & S16 & S17 & S18 & S19 \\
\hline Viviparidae & Nums. & 4 & 3 & 7 & 5 & 7 & 5 & 9 & 5 & 5 & 8 & 5 & 6 & 5 & 5 & 5 & - & 3 & 7 & 6 \\
& A.F.Wt. & 2.36 & 2.06 & 3.29 & 1.29 & 3.59 & 0.89 & 0.56 & 0.94 & 1.42 & 0.43 & 0.89 & 1.02 & 1.37 & 1.01 & 0.74 & - & 0.52 & 0.81 & 0.75 \\
C. japonicus & Nums. & 1 & 1 & 2 & 1 & 2 & 2 & 2 & 2 & 2 & 2 & 3 & 2 & 1 & 2 & 3 & 1 & 3 & 2 & 2 \\
Sharp & A.F.Wt. & 2.34 & 2.41 & 2.65 & 1.95 & 3.03 & 2.78 & 2.35 & 3.19 & 2.12 & 3.02 & 1.97 & 2.36 & 2.16 & 3.03 & 3.41 & 2.67 & 2.35 & 2.43 & 2.15 \\
P. glenni & Nums. & 2 & 2 & 3 & 5 & 3 & 10 & 11 & 6 & 3 & 18 & 4 & 7 & 20 & 12 & 4 & 2 & 6 & 7 & 3 \\
Dybowski & A.F.Wt. & 3.46 & 3.27 & 7.07 & 4.89 & 12.53 & 5.58 & 1.32 & 0.76 & 8.48 & 5.89 & 6.58 & 6.15 & 1.56 & 4.36 & 3.15 & 4.36 & 5.43 & 4.63 & 4.26 \\
\hline
\end{tabular}


Table 2 Concentrations of T-Hg and MeHg in sediment, three organ parts of reed, and three water animal species in Wuyur River (ppb in dry weight, $n=3$ )

\begin{tabular}{|c|c|c|c|c|c|c|c|c|c|c|}
\hline & \multirow[t]{2}{*}{ Sediment } & \multicolumn{3}{|l|}{ Reed } & \multicolumn{2}{|c|}{ Viviparidae } & \multicolumn{2}{|c|}{ C. japonicus Sharp } & \multicolumn{2}{|c|}{ P. glenni Dybowski } \\
\hline & & Root & Rhizome & Stem & $\mathrm{T}-\mathrm{Hg}$ & $\mathrm{MeMg}$ & $\mathrm{T}-\mathrm{Hg}$ & $\mathrm{MeMg}$ & $\mathrm{T}-\mathrm{Hg}$ & $\mathrm{MeMg}$ \\
\hline S1 & 290 & 46.78 & 12.72 & 6.14 & 56.23 & 32.38 & 66.47 & 33.94 & 80.45 & 72.90 \\
\hline S2 & 360 & 88.67 & 24.54 & 10.62 & 95.48 & 54.85 & 128.49 & 72.02 & 156.47 & 112.96 \\
\hline S3 & 350 & 61.35 & 18.55 & 9.64 & 85.16 & 41.95 & 135.76 & 62.45 & 135.47 & 100.32 \\
\hline S4 & 310 & 76.37 & 36.53 & 7.39 & 79.88 & 26.11 & 118.48 & 63.86 & 125.37 & 96.26 \\
\hline S5 & 320 & 70.63 & 33.67 & 8.14 & 82.31 & 39.86 & 116.78 & 68.08 & 108.12 & 88.72 \\
\hline S6 & 410 & 86.7 & 40.25 & 11.21 & 112.04 & 48.53 & 153.154 & 109.83 & 122.74 & 107.56 \\
\hline S7 & 340 & 23.97 & 10.48 & 8.38 & 102.36 & 47.42 & 120.89 & 73.73 & 112.12 & 84.90 \\
\hline S8 & 330 & 31.39 & 10.78 & 7.64 & 79.56 & 30.51 & 102.36 & 82.84 & 90.24 & 74.30 \\
\hline S9 & 375 & 43.78 & 15.56 & 9.88 & 110.45 & 40.02 & 138.15 & 76.35 & 133.45 & 90.46 \\
\hline S10 & 310 & 35.48 & 12.6 & 7.14 & 104.65 & 43.07 & 208.34 & 100.39 & 182.19 & 148.74 \\
\hline S11 & 170 & 19.48 & 6.45 & 4.89 & 56.78 & 30.65 & 68.45 & 33.95 & 92.45 & 67.70 \\
\hline $\mathrm{S} 12$ & 140 & 11.12 & 5.67 & 3.01 & 50.47 & 22.11 & 65.215 & 32.96 & 76.45 & 45.56 \\
\hline S13 & 160 & 15.63 & 6.487 & 3.84 & 39.59 & 17.85 & 42.02 & 28.93 & 40.16 & 27.02 \\
\hline S14 & 90 & 24.57 & 9.43 & 5.39 & 28.45 & 12.31 & 46.27 & 18.29 & 39.87 & 20.48 \\
\hline S15 & 310 & 33.87 & 11.27 & 6.88 & 103.27 & 46.11 & 133.47 & 53.94 & 112.47 & 90.774 \\
\hline S16 & 390 & 54.47 & 24.05 & 7.13 & 138.14 & 84.78 & 189.09 & 130.90 & 143.02 & 126.91 \\
\hline S17 & 230 & 35.46 & 27.86 & 4.85 & 108.36 & 82.09 & 120.36 & 66.57 & 114.45 & 102.64 \\
\hline S18 & 210 & 20.78 & 9.67 & 5.64 & 89.45 & 30.48 & 99.23 & 34.39 & 102.12 & 40.78 \\
\hline S19 & 260 & 48.89 & 18.76 & 6.88 & 99.09 & 60.07 & 156.25 & 72.04 & 132.36 & 74.34 \\
\hline
\end{tabular}

we used a reagent blank composed of $30 \% \mathrm{HCl}$ to set a zero reading. To verify the performance of the instrument, a certified reference material was analyzed before, during, and at the end of every run.

$\mathrm{MeHg}$ was extracted from the tissues of water animals and red-crowned cranes according to the method developed by Zheng et al. [27]. These tissues were dried in their digestion vessels. All of the subsamples were then heated overnight at approximately $60{ }^{\circ} \mathrm{C}$ prior to the addition of $50 \mathrm{ml}$ of $2 \mathrm{M} \mathrm{HCl}$ and $1 \mathrm{ml}$ of $1 \% \mathrm{CuSO}_{4}$ solution. After shaking for $10 \mathrm{~min}$, the solution was filtered. The samples were buffered to $\mathrm{pH} 4$ with either $2 \mathrm{M} \mathrm{HCl}$ or $6 \mathrm{M} \mathrm{NaOH}$ solution. Thereafter, the filtrate was passed through a sulfhydryl cotton tube filled with $0.1 \mathrm{~g}$ cotton and was eluted by $1 \mathrm{ml}$ of $2 \mathrm{M} \mathrm{HCl}$ solution. This process was repeated twice more under additional solvent $(1 \mathrm{ml})$. MeHg was extracted from the elution with benzene. It was then analyzed by gas chromatography with electron capture detection and a detection limit of $0.1 \mu \mathrm{g} \mathrm{kg}^{-1}$.

We estimated the precision and accuracy of the applied analytical method based on certified reference materials (GBW-07601 for T-Hg, 0.36 $\pm 0.05 \mathrm{mg} \mathrm{kg}^{-1}$; GBW-07604 for $\mathrm{MeHg}, 0.026 \pm 0.003 \mathrm{mg} \mathrm{kg}^{-1}$ ) in relation to the measured values (trace metals in fish muscle and the feathers of the red-crowned crane). The results agreed with the certified values for all metals, with average recovery rates of 91.7 and $92.4 \%$ for $\mathrm{T}-\mathrm{Hg}$ and $\mathrm{MeHg}$, respectively. All of the materials used for sampling and analysis were acidwashed. Moreover, all of the samples were analyzed in triplicate at a relative standard deviation lower than $1.5 \%$.
Fig. 2 Relation between the concentrations (dry weight) of total mercury and methyl mercury in three aquatic animals (a Viviparidae, b C. japonicus Sharp, c P. glenni Dybowski)
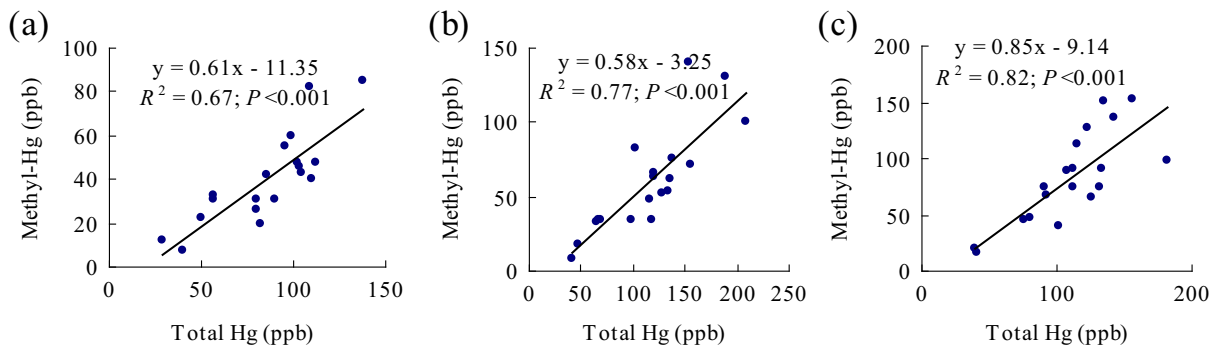


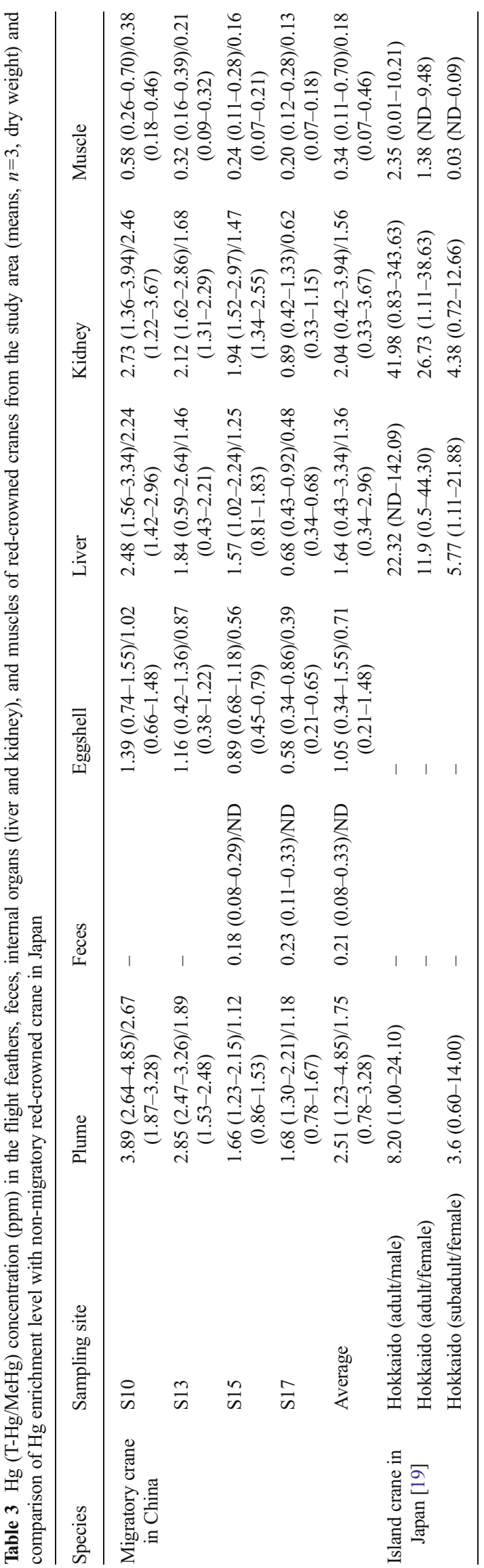

Statistical Analysis

SPSS 10.0 for Windows was used for data analysis. Analysis of variance (ANOVA) was employed to test whether $\mathrm{Hg}$ concentrations varied significant between the reed organs and water animals in the buffer zone and core area. Possibilities less than $0.05(p<0.05)$ were considered statistically significant, and Pearson's correlation coefficients were used to calculate correlations between the $\mathrm{T}-\mathrm{Hg}$ and $\mathrm{MeHg}$ in the tissues of three aquatic animals and samples of red-crowned crane.

\section{Results}

Hg Contaminations in the Prey

In the sediments, $\mathrm{Hg}$ contents generally exceeded the upper limit of the natural background values $(120 \mathrm{ppb})$ and ranged from 90 to $410 \mathrm{ppb}$ (Table 2), with the exception of site S14. In the buffer zone of Zhalong Wetland, almost all of the $\mathrm{Hg}$ surpassed the $\mathrm{Hg}$ range (20 to $290 \mathrm{ppb}$ ) in China as reported by Kabata-Pendias [28]. At site S16, Hg concentration was extremely high at $410 \mathrm{ppb}$. This value exceeds the tolerable level $(400 \mathrm{ppb})$ for agro-economic crops as provided by Kabata-Pendias [28].

Reed, as the preferred food of the red-crowned cranes in Zhalong wetland, was found to contain measurable levels of $\mathrm{Hg}$, with the following order of increasing concentration: stem $<$ rhizome $<$ root (Table 2). The T-Hg concentrations in the reed root and rhizome varied from 11.12 to $88.67 \mathrm{ppb}$ and from 5.67 to $40.25 \mathrm{ppb}$. The contents of T-Hg in reed root were correlated with the concentrations in the sediment at the significant level of $0.01(r=0.78, p<0.001)$. T-Hg contents in sediments and reed organs of the buffer zone were significantly larger than these in the core area $(F=17.29, p<0.001$, for sediment; $F=10.33, p=0.005$, for reed root; $F=6.56, p=0.04$, for rhizome; and $F=20.56, p<0.001$, for reed stem).

$\mathrm{Hg}$ was detected in the tissues of three aquatic animals. This $\mathrm{Hg}$ mainly came in the form of $\mathrm{MeHg}$ (61\% in Viviparidae, $58 \%$ in C. japonicus Sharp, and $85 \%$ in P. glenni Dybowski) (Table 2, Fig. 2). The Viviparidae family is the primary consumer and prefers to feed on reed leaves and humus in the sediments. This species accumulates relatively low concentrations of T-Hg and $\mathrm{MeHg}$ (28.45 to $138.14 \mathrm{ppb}$ and 12.31 to $84.78 \mathrm{ppb}$, respectively). By contrast, the aquatic animals in the high trophic level of the food chain (i.e., the secondary consumers $P$. glenni Dybowski and C. japonicus Sharp families, which mainly prey on fish and the larvae of aquatic insects) had higher concentrations (42.02 to $208.34 \mathrm{ppb}$ and 18.29 to $130.90 \mathrm{ppb}$ of T-Hg and $\mathrm{MeHg}$, respectively, in C. japonicus Sharp; 39.87 to $182.19 \mathrm{ppb}$ and 
Table 4 Correlation of $\mathrm{T}-\mathrm{Hg}$ and $\mathrm{MeHg}$ in the feather and three internal organs of red-crowned crane

\begin{tabular}{lllll}
\hline & Plume & Eggshell & Liver & Kidney \\
\hline Eggshell & $0.923 / 0.936$ & 1 & & \\
Liver & $0.870 / 0.915$ & $0.985^{\mathrm{a}} / 0.942$ & 1 & 1 \\
Kidney & $0.880 / 0.872$ & $0.967^{\mathrm{a}} / 0.933$ & $0.992^{\mathrm{b}} / 0.993^{\mathrm{b}}$ & $0.925 / 0.919$ \\
Muscle & $0.960^{\mathrm{a}} / 0.965^{\mathrm{a}}$ & $0.896 / 0.893$ & $0.886 / 0.960^{\mathrm{a}}$ & 1 \\
\hline
\end{tabular}

${ }^{\text {a }}$ Significant at 0.05 level (two-tailed)

${ }^{\mathrm{b}}$ Significant at 0.01 level (two-tailed)

20.48 to $148.74 \mathrm{ppb}$ of $\mathrm{T}-\mathrm{Hg}$ and $\mathrm{MeHg}$, respectively, in P. glenni Dybowski).

\section{$\mathrm{Hg}$ in the Red-Crowned Cranes}

The red-crowned cranes accumulated measurable levels of $\mathrm{Hg}$. The order of contamination is as follows: feces $<$ muscle $<$ eggshell $<$ liver $<$ kidney $<$ feathers (Table 3 ). The feathers contained the highest concentrations of $\mathrm{T}-\mathrm{Hg}$ and $\mathrm{MeHg}$ at 3.89 and $2.67 \mathrm{ppm}$, respectively. Furthermore, the Hg concentration in the internal organs was relatively high. In the kidney, T-Hg content varied from 0.89 to $2.73 \mathrm{ppm}$, and $\mathrm{MeHg}$ concentration ranged from 0.62 to $2.46 \mathrm{ppm}$. In the liver, T-Hg varied from 0.68 to $2.48 \mathrm{ppm}$, and $\mathrm{MeHg}$ concentration ranged from 0.48 to $2.24 \mathrm{ppm}$. Furthermore, these organs were the most prone to $\mathrm{Hg}$ accumulation, i.e., the $2.73 \mathrm{ppm}$ of $\mathrm{T}-\mathrm{Hg}$ accumulated in the kidney was below the sublethal level (3 to $13 \mathrm{ppm}$ ) recommended by Eisler [3]. The feces had the lowest T-Hg concentration at 0.18 to $0.23 \mathrm{ppm}$. Moreover, the $\mathrm{MeHg}$ concentrations were close to the analytical detection limits. The muscles also possessed low metal concentrations. In the eggshells obtained from sites S10 and $\mathrm{S} 13$, the T-Hg concentrations were 1.39 and $1.16 \mathrm{ppm}$, respectively, which were above the sublethal level (1 ppm) of $\mathrm{Hg}$ content in bird eggs according to Burger and Gochfeld [22]. In addition, T-Hg concentration is significantly lower in the migratory red-crowned cranes of China than in the resident cranes of Japan $(F=37.78, p<0.001)$.
The T-Hg and MeHg concentrations in the eggshells were significantly correlated with those in the liver and kidney $(r=0.985, p<0.001$, for eggshell vs. liver; $r=0.967$, $p<0.001$, for eggshell vs. kidney). However, these concentrations were not significantly correlated with those in the muscle (Table 4). Nonetheless, $\mathrm{T}-\mathrm{Hg}$ and $\mathrm{MeHg}$ in the muscle were significantly correlated with those in the feathers $(r=0.960$, $p<0.001$ ). In the core area (main habitat of the red-crowned crane), the daily intake of $\mathrm{Hg}$ by these cranes ranged from 39.94 to $48.03 \mathrm{ppb}$, whereas the intake ranged from 54.39 to $65.09 \mathrm{ppb}$ in the buffer zone (breeding and foraging sites for other protected water birds) (Table 5). Based on the average concentrations, $\mathrm{T}-\mathrm{Hg}$ and $\mathrm{MeHg}$ were bioconcentrated and biomagnified through the food chain in Zhalong Wetland, as presented in Fig. 3.

\section{Discussions}

The present study reveals two little known adverse effects of $\mathrm{Hg}$ (primarily $\mathrm{MeHg}$ ) on the bodies of red-crowned cranes in China's Zhalong Wetland. First, the prey of these cranes contained measurable levels of $\mathrm{T}-\mathrm{Hg}$ and $\mathrm{MeHg}$, but the dietary exposure level of this population to $\mathrm{Hg}$ was below the Hg toxicity threshold. Second, the Hg concentration levels in the feathers and eggshells of these cranes were significantly high and were correlated with those in their internal organs (i.e., liver, kidneys, and muscles). However, the $\mathrm{Hg}$ content in
Table 5 Estimated intake rates of $\mathrm{Hg}$ for the migratory red-crowned crane population using the five major types of their food

\begin{tabular}{llll}
\hline Item & Food consumed $\left(\mathrm{g} \mathrm{day}^{-1}\right)$ & \multicolumn{2}{l}{ Contents $(\mathrm{ppb})$} \\
\cline { 4 - 4 } & & Buffer zone & Core area \\
\hline Reed stem & $110-130$ & 8.46 & 5.17 \\
Reed rhizome & $140-160$ & 21.31 & 12.61 \\
Viviparidae & $100-140$ & 91.56 & 76.81 \\
P. glenni Dybowski & $120-140$ & 125.36 & 90.12 \\
C. japonicus Sharp & $200-230$ & 131.37 & 95.54 \\
Total & $670-770[35]$ & $54.39-65.09$ & $39.94-48.03$ \\
\hline
\end{tabular}


Fig. 3 Average content $\pm \mathrm{SD}$ of $\mathrm{T}-\mathrm{Hg}$ in sediments, reed stems, three water animal families, and red-crowned crane $(n=3$, dry weight)

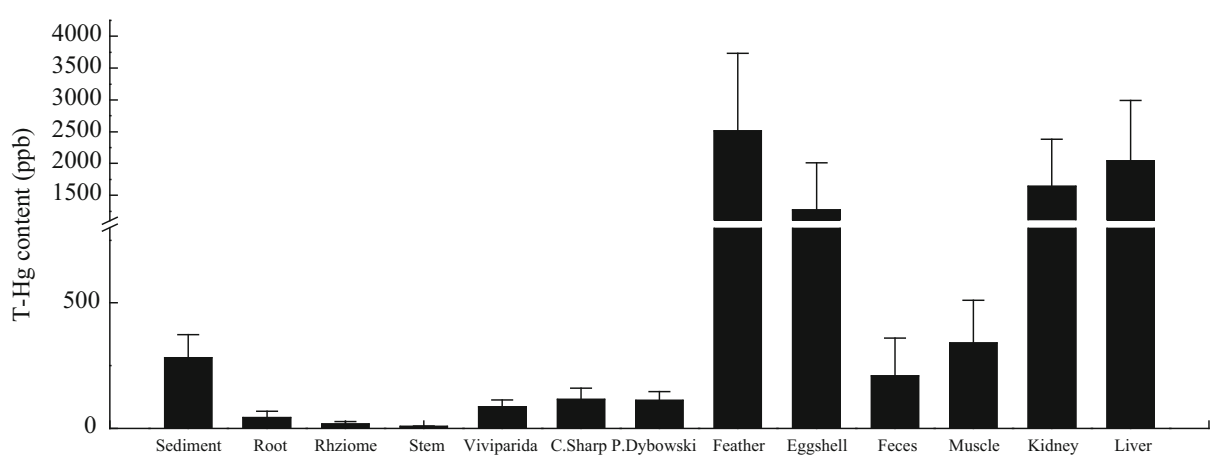

the feces of the water bird was either low or even below the detection limit.

The finding of this study agreed with the conclusion drawn by Eisler [3] with respect to the bioaccumulation of $\mathrm{Hg}$ in the habitat of the red-crowned crane. According to Eisler [3], $\mathrm{Hg}$ is not only bioconcentrated by organisms but also biomagnified through the food chain. Barr [29] determined that loons laid fewer eggs when the $\mathrm{Hg}$ concentrations in their prey averaged 300 to $400 \mathrm{ppb}$. Furthermore, they did not lay eggs when this average exceeded $400 \mathrm{ppb}$. In the current study, the $\mathrm{Hg}$ contents in all of the prey did not exceed the allowable concentration limit (200 ppb) recommended by Agah et al. [30] and the toxicity threshold concentration (300 ppb) provided by Barr [29]. This result suggests that the incidence of $\mathrm{Hg}$ in prey does not contribute highly to the diets of water birds (such as red-crowned cranes and other water fowls) in this region.

The present study reveals that $\mathrm{MeHg}$ dominates the $\mathrm{Hg}$ content in prey tissues and in the bodies of water birds. This finding is consistent with those of many previous researches. According to Burger and Gochfeld [22] and Evers et al. [31], muscle tissue provides the protein used to form feathers. Furthermore, the feathers are among the few body compartments in which $\mathrm{MeHg}$ can be remobilized. Therefore, the $\mathrm{Hg}$ concentrations in feathers during growth can indicate $\mathrm{MeHg}$ contamination in the body of the red-crowned crane. In the current study, the T-Hg concentrations in the feathers of the red-crowned crane in Zhalong Wetland were similar to the average $\mathrm{Hg}$ concentrations in the Little Egrets of Tai Lake $(0.64 \mathrm{ppm})$ and Poyang Lake $(0.41 \mathrm{ppm})$ in Southern China as well as those of Common Eiders in Aleutian Island (0.98 ppm) and in the Amchitak and Kiska area (0.64 ppm) as reported by Zhang et al. [4] and Burger et al. [8]. However, the concentrations determined by the present study were lower than those in the Little Egrets of Pearl Delta $(2.09$ ppm $)(p<0.05)$ in China.

In the current study, the increasing $\mathrm{Hg}$ content in the feathers of red-crowned cranes demonstrated that crane feathers are prone to $\mathrm{Hg}$ contamination, as with the feathers of many other birds $[8,22]$. The T-Hg and $\mathrm{MeHg}$ concentrations in the feathers of the red-crowned crane exceed those in their internal organ tissues (liver and kidney). This finding contradicts those of many previous researches. This discrepancy is most likely influenced by external contamination (i.e., atmospheric deposition) because exogenous fractions of heavy metals cannot be completely removed by washing alone [17]. Therefore, the use of crane feathers as indicators of $\mathrm{Hg}$ pollution may be challenged, and further research is recommended.

The T-Hg and MeHg concentrations in the eggshells are strongly correlated with those in the liver and kidney. However, they are not significantly correlated with the concentrations in the muscle. This result agrees with that of Evers et al. [31], which postulates that $\mathrm{MeHg}$ in the muscle contributes only slightly to $\mathrm{Hg}$ concentration in the developing egg. Burger et al. [8] reported that the $\mathrm{T}-\mathrm{Hg}$ content in eggs normally ranges between 10 and $20 \%$ of that in the liver. In the present study, the eggshells of the red-crowned crane removed $\mathrm{Hg}$ from its body, as indicated by the relatively high $\mathrm{T}-\mathrm{Hg}$ and $\mathrm{MeHg}$ concentrations therein. The eggshells of birds such as the Great Tit (Parus major) [16] and common loon [5, 16] perform a similar function. Given that Chinese law prohibits the intentional killing of wild cranes and the picking of their eggs, the eggshells of these birds can effectively indicate the Hg risk level to the red-crowned crane.

Our results showed that the T-Hg concentrations in feces were low and that $\mathrm{MeHg}$ concentrations therein were below the analytical detection limit. Dauwe et al. [16] determined that the Great Tit could excrete Hg from its body. Hence, its feces can indicate the pollution levels in a metal-contaminated region. Conversely, Leonzio et al. [32] reported that the total $\mathrm{Hg}$ and $\mathrm{MeHg}$ concentrations in feces are limited. Our results confirm this finding because the feces of the red-crowned crane do not always reflect the contamination status of $\mathrm{Hg}$ in its body. Thus, excretions may not be a suitable indicator of $\mathrm{Hg}$ risk level.

Similar to the results reported by Takazawa et al. [33] and Malik et al. [34], we determined relatively high $\mathrm{Hg}$ contents in the kidney and liver tissues of the red-crowned crane. According to these previous studies, the livers and kidneys of water fowls are prone than other internal organs to the accumulation of many toxic metals, such as Hg. According to Eisler [3], Hg 
concentrations that exceed $3 \mathrm{ppm}$ in kidney or liver tissue are presumptive evidence of an environmental $\mathrm{Hg}$ problem. In the present study, however, the T-Hg concentrations in the internal organs of the red-crowned crane were below the concentration threshold of $\mathrm{Hg}$ toxicity, thereby suggesting that the Hg risk level to the red-crowned crane was low.

The daily Hg intake of the red-crowned crane (39.94 to $48.03 \mathrm{ppb}$ ) was significantly lower than the concentration at the sublethal effect level recommended by Eisler [3] for sensitive aquatic bird species (i.e., 100 to $500 \mathrm{ppb}^{\mathrm{day}}{ }^{-1}$ ). Hence, we regard the level of dietary exposure of the migratory red-crowned cranes to $\mathrm{Hg}$ as safe in China. However, the elevated $\mathrm{Hg}$ levels in the buffer zone of Zhalong Wetland and the detectable levels of $\mathrm{T}-\mathrm{Hg}$ and $\mathrm{MeHg}$ in red-crowned cranes should be examined further.

Acknowledgments This research was funded by the school of supporting youth's academic backbone project in Heilongjiang Province of China (grant no. 1253G063), Heilongjiang Province Environmental Geography College Key Laboratory of remote sensing monitoring project. We extend our appreciation to Wang WF and Gao ZY of Zhalong National Nature Reserve for their suggestions and help for field sample collection.

Open Access This article is distributed under the terms of the Creative Commons Attribution License which permits any use, distribution, and reproduction in any medium, provided the original author(s) and the source are credited.

\section{References}

1. Burger J, Gochfeld M (1997) Risk, mercury levels, and birds: relating adverse laboratory effects to field biomonitoring. Environ Res 75: $160-172$

2. National Academy of Science (NAS) (1978) An assessment of mercury in the environment. Natl Acad Sci, Washington, DC

3. Eisler R (1987) Mercury hazards to fish, wildlife, and invertebrates: a synoptic review. US Fish Wildl Serv, Washington, DC. Biol Rep 85(1.10)

4. Zhang Y, Ruan L, Fasola M, Boncompagni E, Dong Y, Dai N, Gandini C, Orvin E, Ruiz X (2006) Little Egrets (Egretta garzetta) and trace metal contamination in wetlands of China. Environ Monit Assess 118:355-368

5. Scheuhammer AM, Meyer MW, Sandheinrich MB, Murray MW (2007) Effects of Environmental methylmercury on the health of wild Birds, mammals, and fish. Ambio 36:12-18

6. U.S. Environmental Protection Agency (EPA) (1980) Ambient water quality criteria for zinc. U.S. Environmental Protection Agency Report 440/5-80-079

7. Kitagishi K, Yamane I (eds) (1981) Heavy metal pollution in soils of Japan. Japan Science Society Press, Tokyo

8. Burger J, Gochfeld M, Jeitner C, Snigaroff D, Snigaroff D, Stamm T, Volz C (2008) Assessment of metals in down feathers of female common eiders and their eggs from Aleutians: arsenic, cadmium, chromium, lead, manganese, mercury, and selenium. Environ Monit Assess 143:247-256

9. Lee HS, Cho YH, Park SO, Kye SH, Kim BH, Hahm TS, Kim M, Lee JO, Kim C (2006) Dietary exposure of the Korean population to arsenic, cadmium, lead and mercury. J Food Compo Analy 19: S31-S37

10. Kenow KP, Hines RK, Meyer MW, Suarez SA, Gray BR (2010) Effects of methylmercury exposure on the behavior of captivereared common loon (Gavia immer) chicks. Ecotoxicology 19: 933-944

11. Martínez-Villegas N, Flores-Vélez LM, Domínguez O (2004) Sorption of lead in soil as a function of $\mathrm{pH}$ : a study case in México. Chemosphere 57:1537-1542

12. Fisk AT, de Wit CA, Wayland M, Kuzyk ZZ, Burgess N, Lethcer R, Branue B, Norstrom R, Blum SP, Sandau C, Lie E, Larsen HJ, Skaare JU, Muir DC (2005) An assessment of toxicological significance of anthropogenic contaminants in Canadian arctic wildlife. Sci Total Environ 351-352:57-93

13. Hansan SA, Fariduddin Q, Ali B (2009) Cadmium: toxicity and tolerance in plants. J Environ Biol 30:165-174

14. Nsikak UB, Joseph PE, Akan BW, David EB (2007) Mercury accumulation in fishes from tropical aquatic ecosystems in the Niger Delta, Nigeria. Curr Sci 92:781-785

15. Fasola M, Movalli PA, Gandini C (1998) Heavy metal, organochlorine pesticide, and PCB residues in eggs and feathers of herons breeding in northern Italy. Arch Environ Contam Toxicol 34:87-93

16. Dauwe T, Bervoets L, Blust R, Pinxten R, Eens M (1999) Are eggshells and egg contents of great and blue tits suitable as indicators of heavy metal pollution? Belg J Zool 129:439-447

17. Dauwe T, Bervoets L, Pinxten R, Blust R, Eens M (2003) Variation of heavy metals within and among feathers of birds of prey: effects of molt and external contamination. Environ Pollut 124:429-436

18. BirdLife International (2012) Grus monacha: IUCN 2012. IUCN red list of threatened species. Version 2012. 4. http:/www.birdlife.org/ datazone/speciesfactsheet. Accessed 5 May 2013

19. Teraoka H, Kumagai Y, Iwai H, Haraguchi K, Ohba T, Nakai K, Satoh H, Sakamoto M, Momose K, Masatomi H, Hiraga T (2007) Heavy metal contamination status of Japanese cranes (Grus japonensis) in east Hokkaido, Japan-extensive mercury pollution. Environ Toxicol Chem 26:307-312

20. Harris J (2008) Cranes respond to climate change. ICF Bugle 34(13):14-15

21. Koller LD (1980) Immunotoxicology of heavy metals. Int J Immunopharmacol 2:269-279

22. Burger J, Gochfeld M (1993) Lead and cadmium accumulation in eggs and edgling seabirds in the New York Bight. Environ Toxicol Chem 12:261-267

23. Luo J, Yin X, Ye Y, Wang Y, Zang S, Zhou X (2013) Pb and Cd bioaccumulations in the habitat and preys of red-crowned cranes (Grus japonensis) in Zhalong wetland, northeastern China. Biol Trace Elem Res 156:134-143

24. Luo J, Ye Y, Yin X (2014) Bioaccumulation and dietary exposure of the red-crowned cranes (Grus japonensis) to arsenic in Zhalong wetland, northeastern China. Aquat Ecosys Health Manag. In press

25. USEPA (1996) Method 3050B - acid digestion of sediments, sludges, and soils. U.S. Environmental Protection Agency, USA

26. Canli M, Ay O, Kalay M (1998) Levels of heavy metals (Cd, Pb, $\mathrm{Cu}, \mathrm{Cr}$ and $\mathrm{Ni}$ ) in tissue of Cyprinus carpio, Barbus capito and Chondrostoma regium from the Seyhan River. Turk J Zool 22: 149-157

27. Zheng DM, Wang QC, Zhang ZS, Zheng N, Zhang XW (2008) Bioaccumulation of total and methyl mercury by arthropods. Bull Environ Contam Toxicol 81:95-100

28. Kabata-Pendias A (2001) Trace elements in soils and plants (3rd edn). CRC Press, Boca Raton

29. Barr JF (1986) Population dynamics of the common Loon (Gavia immer) associated with mercury-contaminated waters in northwestern Ontario. Can Wildl Serv, Occas Paper No 56 
30. Agah H, Leermakers M, Elskens M, Mohamad Rez Fatemi S, Baeyens W (2009) Accumulation of trace metals in the muscle and liver tissues of five fish species from the Persian Gulf. Environ Monit Assess 157:499-514

31. Evers DC, Taylor KM, Major A, Taylor RJ, Poppenga RH, Scheuhammr AM (2003) Common loon eggs as indicators of methylmercury availability in North America. Ecotoxicology 12:69-81

32. Leonzio C, Bianchi N, Gustin M, Sorace A, Ancora S (2009) Mercury, lead and copper in feathers and excreta of small passerine species in relation to foraging guilds and age of feathers. Bull Environ Contam Toxicol 83:693-697
33. Takazawa Y, Kitamura K, Yoshikane Y, Morita M (2004) Discovery of fenthion poisoning in two Japanese cranes (Grus japonensis) found dead in Hokkaida, Japan. Bull Environ Contam Toxicol 73:947-954

34. Malik N, Biswas AK, Qureshi TA, Borana K, Virha R (2010) Bioaccumulation of heavy metals in fish tissues of a freshwater lake of Bhopal. Environ Monit Assess 160: 267-276

35. Ma Y, Li X (2002) Research on the red-crowned crane (Grus japonensis). Shanghai Scientific \& Technological Education Press, Shanghai, P.R. China (in Chinese) 